\title{
Hubungan Higiene, Fasilitas dan Sanitasi Lingkungan Dengan Kualitas Mikrobilogi Serta Identifikasi Eschericia Coli O157: H7 Pada Sate Languan
}

\author{
Sang Gede Purnama ${ }^{1 *}$, Made Subrata ${ }^{1}$ \\ ${ }^{1}$ Program Studi Ilmu Kesehatan Masyarakat, Fakultas Kedokteran, Universitas Udayana, Bali \\ *Corresponding author: sangpurnama@unud.ac.id \\ Info Artikel : Diterima Februari 2019 ; Disetujui September 2019 ; Publikasi Oktober 2019
}

\begin{abstract}
ABSTRAK
Latar belakang: Proses pembuatan Sate Languan yang dari bahan baku ikan rentan mengalami kontaminasi secara mikrobiologi akibat kontaminasi alat luluh yang kurang dibersihkan dan penjamah makanan. Oleh sebab itu, perlu dilakukan identifikasi cemaran dan faktor risikonya.

Metode: penelitian ini menggunakan metode campuran (mixed methode) dengan rancangan penelitian sequential explanatory design yakni menggabungkan dua bentuk penelitian yakni kuantitatif dan kualitatif dimana pada tahap pertama mengambil data kuantitatif selanjutnya data kualitatif. Pendekatan kuantitatif juga dilakukan dengan observasi secara langsung oleh peneliti. Jumlah sampel seluruh pedagang Sate Languan di Pantai Lebih dan sekitarnya sebanyak 19 rumah makan dan 19 sampel Sate Languan. Variabel yang diteliti higiene penjamah makanan, kepemilikan alat luluh, ketersediaan fasilitas sanitasi, sanitasi lingkungan, lama kerja dan pendidikan. Pemeriksaan mikrobiologi dengan identifikasi Eschericia coli O157:H7 dengan pembiakan pada media eosin methylene blue agar (EMBA), identifikasi E. coli O157:H7 dilanjutkan dengan penumbuhan isolate bakteri di media selektif sorbitol MacConkey agar (SMAC) dilanjutkan dengan uji konfirmasi dengan lateks O157.

Hasil: Variabel yang berhubungan dengan kontaminasi Eschericia coli pada Sate Languan yakni higiene penjamah makanan, sarana fasilitas sanitasi dan kepemilikan alat luluh. Higiene penjamah makanan yang termasuk kategori kurang baik sebanyak (79\%), kategori fasilitas sanitasi tidak memadai sebanyak (53\%), kategori sanitasi lingkungan kurang bersih sebanyak (47\%). Dari 19 sampel yang dilakukan pemeriksaan coliform dan E. coli diketahui 15 warung makan terkontaminasi E. coli rata-rata $5 \times 10^{6} \mathrm{cfu} / \mathrm{gram}$ hanya 4 warung yang $E$. coli masih dalam batas aman. Hasil uji lanjutan diketahui bahwa negatif Eschericia coli O157:H7.

Simpulan: Ada hubungan higiene penjamah makanan, sarana fasilitas sanitasi dan kepemilikan alat luluh dengan kontaminasi E. coli. Ditemukan cemaran E. coli pada makanan Sate Languan namun tidak terbukti jenis E. coli $\mathrm{O} 157: \mathrm{H} 7$.
\end{abstract}

Kata kunci : mikrobiologis; sate languan; penjamah makanan

\section{ABSTRACT}

Title: The Relationship of Hygiene, Facilities and Environmental Sanitation with The Identification of Eschericia Coli O157: $H 7$ at Languan Satay.

Background: The process of processing satay from raw material from chopped fish is susceptible to microbiological contamination due to unclean contamination of equipment and food handlers. Therefore, it is necessary to identify contaminants and risk factors. 
Methods: This study uses (mixed method) a sequential explanatory design that combines two forms of research, namely quantitative and qualitative, where in the first stage, the quantitative data is then taken from qualitative data. The quantitative approach is also carried out by direct observation by the researcher. The total sample of all satay traders in Lebih Beach and surrounding areas are 19 restaurants and 19 samples of Languan Satay. The variables studied were food handler hygiene, ownership of meat crusher, availability of sanitation facilities, environmental sanitation, length of work and education. Microbiological examination with identification of Escherichia coli O157: $H 7$ with culture on eosin methylene blue agar (EMBA) media, identification of E. coli O157: H7 followed by growth of bacterial isolates in selective Sorbitol Mac Conkey agar (SMAC) followed by confirmation test with O157 latex.

Results: variables related to Escherichia coli contamination in satay is food handler hygiene, sanitation facilities and ownership of meat crusher. Food handler hygiene included in the poor category (79\%), inadequate sanitation facilities category (53\%) and less clean environmental sanitation category (47\%). Of the 19 samples that were examined for coliform and E. coli, it was found that 15 stalls contaminated with E. coli averaged $5 \times 10^{6} \mathrm{cu} /$ gram, only 4 stalls which were still within safe limits. The results of the follow-up test revealed that negative Eschericia coli O157: $H 7$.

Conclusion:There is a relationship between food handler hygiene, sanitation facilities and ownership of tool with E. coli contamination.It was found E. coli contamination in Languan Satay but it was not proven to be E. coli O157: H7.

Keywords: microbiology; languan sate; food handlers

\section{PENDAHULUAN}

Sate languan adalah salah satu produk kuliner makanan khas Bali yang cukup dikenal. Bahan dasar Sate Languan dari ikan yang dicacah menggunakan alat dan digiling kemudian dipanggang. Sate languan sangat terkenal di daerah Pantai Lebih, Gianyar. Seringkali wisatawan lokal maupun mancanegara singgah ke rumah makan di kawasan pantai untuk menikmati makanan khas ini.

Makanan tradisional Bali masih rentan terhadap kontaminasi mikrobiologi. ${ }^{1,2}$ hal ini dapat dipengaruhi karena kontaminasi penjamah dan peralatan yang digunakan. Penelitian pada makanan Lawar di Gianyar juga menemukan adanya kontaminasi mikrobiologi yang tinggi. ${ }^{3}$ Penelitian di Kawasan Wisata Kuta juga menunjukkan hasil yang sama ${ }^{1}$. Kerentanan makanan tradisional Bali terhadap kontaminasi bakteri perlu mendapatkan perhatian serius semua pihak karena terkait dengan kesehatan wisatawan. Banyak wisatawan datang ingin menikmati wisata kuliner khususnya makanan tradisional Bali sehingga perlu mengetahui penyebab dan upaya mengatasi kontaminasi makanan.

Eschericia coli O157:H7 termasuk kelompok enterenterohaemorrhagic E. coli (EHEC) yang patogen yang memproduksi shiga like toxin yang berbahaya bagi manusia. ${ }^{4}$ Pemeriksaan kandungan $E$. Coli $\mathrm{O} 157$ perlu dilakukan untuk mengetahui tingkat kontaminasi dari makanan tersebut. Penelitian di Afrika Selatan berhasil mendeteksi adanya cemaran $E$. coli $\mathrm{O} 157: \mathrm{H} 7$ pada daging babi, sapi, kotoran manusia dan kotoran hewan. ${ }^{5}$ Adanya kandungan E. coli $\mathrm{O} 157$ dapat membahayakan produk makanan yang dipasarkan.

Proses pengolahan Sate Languan rentan untuk terjadinya kontaminasi makanan dimana dilakukan pencacahan dan penyimpanan bahan dalam suhu yang terkadang tidak ideal. Identifikasi bakteri patogen diperlukan untuk mengetahui tingkat cemarannya sehingga mampu melakukan upaya pencegahan tingkat kontaminasinya.

Tujuan dari penelitian ini adalah mengetahui hubungan antara higiene penjamah, fasilitas dan sanitasi lingkungan terhadap kualitas mikrobiologi makanan sate languan serta mengidentifikasi keberadaan Eschericia coli O157: H7.

\section{MATERI DAN METODE}

Penelitian ini menggunakan metode campuran (mixed method) dengan rancangan penelitian sequential explanatory design yakni menggabungkan dua bentuk penelitian yakni kuantitatif dan kualitatif dimana pada tahap pertama mengambil data kuantitatif selanjutnya data kualitatif. Pengumpulan data kuantitatif dilakukan dengan melakukan observasi secara langsung oleh peneliti. Data yang diperoleh dianalisis untuk mengetahui pengaruh variabel satu dengan yang lainnya. Pendekatan kualitatif dilakukan untuk mengetahui penyebab mengapa adanya kontaminasi $E$. coli pada makanan, persepsi pedagang tentang higiene, persepsi pemilik alat luluh sate dengan wawancara mendalam pada 7 responden terdiri dari 5 orang pedagang, 2 pemilik alat luluh sate. Hasil wawancara tersebut kemudian di transkrip wawancara dan dianalisis isi sesuai tema yang terkait.

Tempat penelitian ini dilakukan di Pantai Lebih Gianyar, Bali. Sampel diambil pada seluruh pedagang di wilayah Pantai Lebih sebanyak 19 warung. Data yang dikumpulkan pada penelitian ini adalah data primer yang berupa karakteristik penjamah makanan (umur, jenis kelamin, pendidikan, lama kerja), praktik higiene penjamah makanan, ketersediaan fasilitas sanitasi, dan kebersihan lingkungan berdasarkan observasi di lokasi penelitian menggunakan formulir check list. Sampel Sate Languan diambil langsung 
dari pedagang Sate Languan dan disimpan dalam termos es dan dibawa ke laboratorium.

Identifikasi Escherichia coli dilakukan dengan metode pengenceran ini menggunakan suatu seri pengenceran dari sampel yang kemudian ditanam pada medium. Setelah diinkubasi, koloni yang tumbuh dapat dihitung dengan asumsi bahwa satu koloni yang tumbuh berasal dari satu sel. Sampel yang sudah diencerkan diambil sebanyak $0,1 \mathrm{ml}$ dan diinokulasi diatas media agar yang telah disiapkan untuk E.coli gunakan media Eosin Methylene Blue Agar (EMBA). Selanjutnya sampel disebar dengan batang kaca bengkok hingga tersebar merata diatas permukaan agar. Selanjutnya cawan petri diinkubasi di inkubator (posisi terbalik) pada suhu $37^{\circ} \mathrm{C}$ selama 24 jam. Setelah diinkubasi koloni yang tumbuh dan berwarna hijau metalik dihitung sebagai koloni $E$. coli.

Koloni positif $E$. coli dari media EMBA yang ditanam pada nutrient agar miring selanjutnya diinokulasikan pada media sorbitol MacConkey Agar (SMAC). Setelah diinkubasikan pada suhu $37^{\circ} \mathrm{C}$ selama 20-24 jam, serotipe E. coli O157:H7 dideteksi dari terlihatnya koloni jernih dan dianggap bersifat sorbitol negatif. ${ }^{6}$ Untuk konfirmasi yang lebih meyakinkan bahwa koloni tersebut adalah serotipe $E$. coli O157, maka pengujian dilanjutkan dengan menggunakan E. coli O157 Latex Agglutination Test (Oxoid DR620 M). Reaksi positif ditandai dengan terbentuknya presipitasi pada kertas lateks sesuai dengan kontrol.

\section{HASIL DAN PEMBAHASAN}

Praktik higiene penjamah makanan kategori kurang, lebih banyak dibandingkan dengan praktik kategori baik. Hal ini dapat dilihat pada Tabel 1 . Bahwa dari 19 responden yang termasuk kategori kurang baik sebanyak 15 responden (79\%), sedangkan responden yang termasuk kategori baik sebanyak 4 responden $(21 \%)$. Hasil dari observasi terhadap kebiasaan mencuci tangan setelah meracik bahan mentah sebagian besar $(70,83 \%)$ sudah dilakukan oleh responden. Selain itu, hampir semua penjamah memiliki kuku pendek dan bersih $(79,17 \%)$, serta biasa membersihkan tempat setelah selesai berjualan $(87,50 \%)$. Namun, penjamah makanan tersebut sebagian besar $(83,33 \%)$ tidak memakai celemek dan $(100 \%)$ tidak memakai tutup kepala saat bekerja.

Ketersediaan fasilitas sanitasi dikategorikan menjadi fasilitas sanitasi memadai dan fasilitas sanitasi kurang memadai. Kategori fasilitas sanitasi tidak memadai sebanyak 9 responden (47\%), sedangkan fasilitas sanitasi memadai sebanyak 10 responden (53\%). Hasil dari observasi pada tempat berjualan responden, sebagian besar $(79,17 \%)$ sudah memiliki fasilitas tempat cuci alat masak dan alat makan, serta $(91,67 \%)$ menggunakan sabun cuci piring. Warung makan sate $(75,00 \%)$ yang tidak memiliki toilet untuk konsumen maupun pedagang. Hampir seluruh tempat tidak memiliki tempat sampah yang tertutup (95,83\%), karena sebagian besar mereka menggunakan tempat sampah yang terbuka atau hanya menggunakan plastik saja.

Kebersihan lingkungan sekitar tempat responden berjualan dikategorikan menjadi lingkungan bersih dan lingkungan kurang bersih. Responden yang termasuk kategori lingkungan kurang bersih sebanyak 9 responden (47\%), sedangkan yang termasuk kategori lingkungan bersih sebanyak 10 responden $(53 \%)$. Hasil dari observasi yang dilakukan, sebagian besar $(75 \%)$ tempat berjualan responden tidak terdapat sampah berserakan. Namun, terdapat $66,67 \%$ tempat berjualan yang lantainya tidak dalam keadaan bersih dan $83,33 \%$ tempat berjualan terdapat serangga seperti lalat, nyamuk, kecoa, dan lain sebagainya di sekitar tempat berjualannya. Hanya ada 4 warung makan yang memang memiliki alat luluh sendiri sedangkan sisanya masih memakai menggunakan jasa usaha pengolahan luluh.

Hasil pemeriksaan laboratorium diketahui mengacu standar CFS 2014 ada 4 warung makan yang memenuhi standar jumlah kontaminasi kuman. Dari 19 sampel yang dilakukan pemeriksaan coliform dan $E$. coli diketahui 15 warung terkontaminasi $E$. coli rata-rata $5 \times 10^{6} \mathrm{cfu} / \mathrm{gram}$. Tingginya kontaminasi kuman dalam pembuatan Sate Languan dari terkait proses pembuatannya mulai dari pemilihan bahan baku, proses penggerusan ikan menjadi luluh sate, peralatan yang digunakan, penjamah makanan yang mengkontaminasi serta penyimpanan pada suhu yang standar.

Berdasarkan hasil analisis bivariat pada tabel 2 diketahui bahwa yang berhubungan dengan keberadaan E. coli pada Sate Languan yakni higiene penjamah makanan, kepemilikan alat luluh dan ketersediaan fasilitas sanitasi. Sedangkan variabel lainnya tidak signifikan hubungannya. Kebiasan pedagang untuk mencuci tangan saat membuat dan mengolah sate luluh sangat berpengaruh terhadap kontaminasi kumannya.

Tabel 1. Distribusi Responden (Penjamah Makanan) menurut Jenis Kelamin, Umur, Pendidikan, Lama Kerja di Pantai Lebih, Bali.

\begin{tabular}{ccc}
\hline Karakteristik Responden & Frekuensi & Presentase (\%) \\
\hline Jenis Kelamin & 1 & 5,3 \\
Laki-laki & 18 & 94,7 \\
Perempuan & & 10,5 \\
Umur & 2 &
\end{tabular}




$\begin{array}{lcc}\text { Dewasa } & 15 & 78,9 \\ \text { Lansia } & 2 & 10,5 \\ \text { Pendidikan } & 1 & 5,26 \\ \text { Tidak sekolah } & 4 & 21 \\ \text { SD } & 4 & 21 \\ \text { SMP } & 10 & 52,6 \\ \text { SMA } & & \\ \text { Lama Kerja } & 10 & 52,6 \\ <10 \text { tahun } & 3 & 15,7 \\ \text { 10-20 tahun } & 2 & 10,5 \\ \text { 20-30 tahun } & 4 & 21 \\ >30 \text { tahun } & & 21 \\ \text { Higiene penjamah Makanan } & 4 & 79 \\ \text { Baik } & 15 & 47 \\ \text { Kurang Baik } & & 53 \\ \text { Ketersediaan fasilitas sanitasi } & 9 & 53 \\ \text { Memadai } & 10 & 47 \\ \text { Tidak memadai } & & 21 \\ \text { Sanitasi lingkungan } & 10 & 79 \\ \text { Bersih } & 9 & \end{array}$

Tabel 2. Hasil analisis bivariat variabel higiene, sanitasi, fasilitas, lama kerja dan pendidikan

\begin{tabular}{|c|c|c|c|}
\hline \multirow[t]{2}{*}{ Variable penelitian } & \multicolumn{2}{|c|}{ Keberadaan E. coli } & \multirow[t]{2}{*}{ Nilai P } \\
\hline & Positif n (\%) & Negatif n $(\%)$ & \\
\hline \multicolumn{4}{|l|}{ Higiene penjamah makanan } \\
\hline Tidak Baik & $15(79 \%)$ & 0 & 0,00 \\
\hline baik & 0 & $4(21 \%)$ & \\
\hline \multicolumn{4}{|l|}{ Alat luluh } \\
\hline Milik sendiri & $15(79 \%)$ & 0 & 0,00 \\
\hline Milik umum & 0 & $4(21 \%)$ & \\
\hline \multicolumn{4}{|l|}{ Ketersediaan fasilitas sanitasi } \\
\hline Tidak Baik & $10(53 \%)$ & 0 & 0.033 \\
\hline baik & $5(26 \%)$ & $4(21 \%)$ & \\
\hline \multicolumn{4}{|l|}{ Sanitasi lingkungan } \\
\hline kurang Baik & $9(47 \%)$ & 0 & 0,087 \\
\hline baik & $6(32 \%)$ & $4(21 \%)$ & \\
\hline \multicolumn{4}{|l|}{ Pendidikan } \\
\hline Rendah & $9(47 \%)$ & 0 & 0,087 \\
\hline Tinggi & $6(32 \%)$ & $4(21 \%)$ & \\
\hline \multicolumn{4}{|l|}{ Lama kerja } \\
\hline Kurang dari 10 tahun & $6(32 \%)$ & $4(21 \%)$ & 0,085 \\
\hline Lebih dari 10 tahun & $9(47 \%)$ & 0 & \\
\hline
\end{tabular}

*Nilai P dari Fisher estract

Tabel 3. Sumber kontaminasi pada sate languan

\section{SUMBER KONTAMINAN RESIKO KONTAMINAN}

\begin{tabular}{l|l}
\hline Kualitas ikan & $\begin{array}{l}\text { Kualitas ikan yang digunakan berperan ikan rentan jika tidak } \\
\text { dilakukan penyimpanan yang baik sebelumnya. }\end{array}$ \\
Alat luluh sate & $\begin{array}{l}\text { Alat luluh sate jarang dibersihkan dengan disinfektan dan } \\
\text { digunakan berulang kali. }\end{array}$
\end{tabular}




\begin{tabular}{l|l} 
Penjamah makanan & $\begin{array}{l}\text { Kebiasaan tidak mencuci tangan dengan sabun hingga bersih } \\
\text { dapat menimbulkan resiko kontaminasi } E \text {. Coli }\end{array}$ \\
Air bersih & $\begin{array}{l}\text { Sumber air ada yang berasal dari sumur bor jika dekat dengan } \\
\text { septic tank menjadi berisiko tercemar. Beberapa } \\
\text { menggunakan sumber air dari PDAM cukup terkontrol. } \\
\text { Penyimpanan sate languan yang tidak sesuai suhu standar } \\
\text { penyimpanan daging rentan menumbuhkan bakteri patogen. }\end{array}$ \\
\hline
\end{tabular}

Hasil observasi lapangan dan wawancara diketahui bahwa kualitas ikan sebelum diolah berperan besar untuk menjadi sumber kontaminasi mikrobiologi. Tempat penyimpanan ikan yang tidak sesuai standar suhu. Hal ini dapat menimbulkan kontaminasi makanan. Alat pembuatan luluh sate sangat rentan terkontaminasi disebabkan karena tidak dilakukan pencucian dengan disinfektan dan sudah lama digunakan. Sebagian besar pedagang mengambil bahan luluh dari satu sumber yang ternyata alatnya mengkontaminasi bahan hanya 4 pedagang yang mempunyai alat luluh sendiri. Kualitas alat luluh yang digunakan berperan besar terhadap terjadinya kontaminasi E. Coli. Alat yang tidak dibersihkan dengan disinfektan setelah penggunaan rentan terkontaminasi.

Alat luluh untuk membuat sate tersebut kebanyakan pedagang tidak memiliki alat jadi mereka membawa daging mentah ke tempat jasa penggilingan daging. Masalahnya di tempat penggilingan daging setiap habis menggiling daging tidak langsung dibersihkan justru dibiarkan digunakan terus berulang-ulang. Karena tempat penggilingan daging terbuka maka ada lalat yang hinggap di daging tersebut.

Perilaku higiene penjamah makanan dalam proses pembuatan luluh sate cukup berperan. Kebiasaan mencuci tangan dengan sabun sebelum mengambil luluh sate masih rendah. Pedagang harus tertib dalam membersihkan tangannya sebelum mengambil makanan. Sumber air bersih ada yang dari sumur bor dan dari PDAM.

Tempat penyimpanan sate yang sebelum di panggang kurang sesui standar karena sebagian besar menempatkan dalam termos yang suhunya tidak dapat disesuaikan. Kondisi ini rentan menimbulkan kontaminasi dan mempercepat pertumbuhan bakteri. Alat-alat yang digunakan juga perlu dilakukan pencucian secara rutin minimal setelah digunakan.

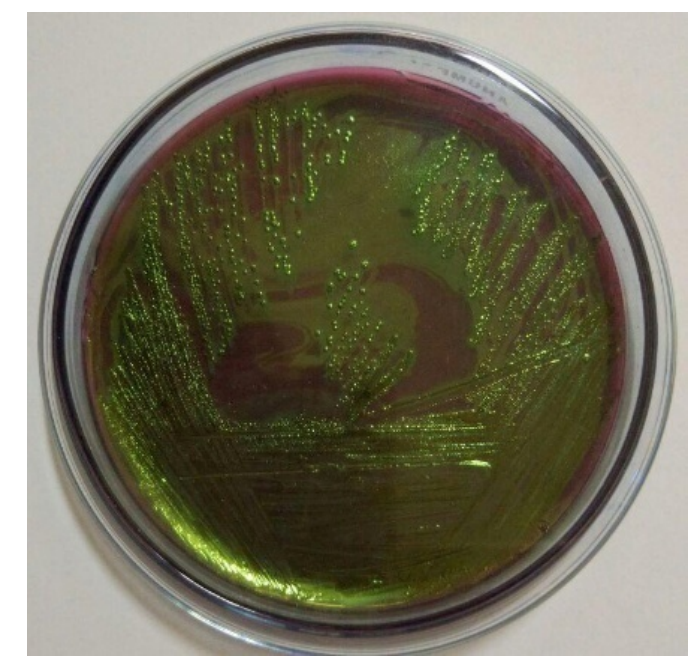

Gambar 1. Tampak Eschericia coli berwarna hijau metalik menggunakan biakan media Eosin Methylene Blue Agar (EMBA) 

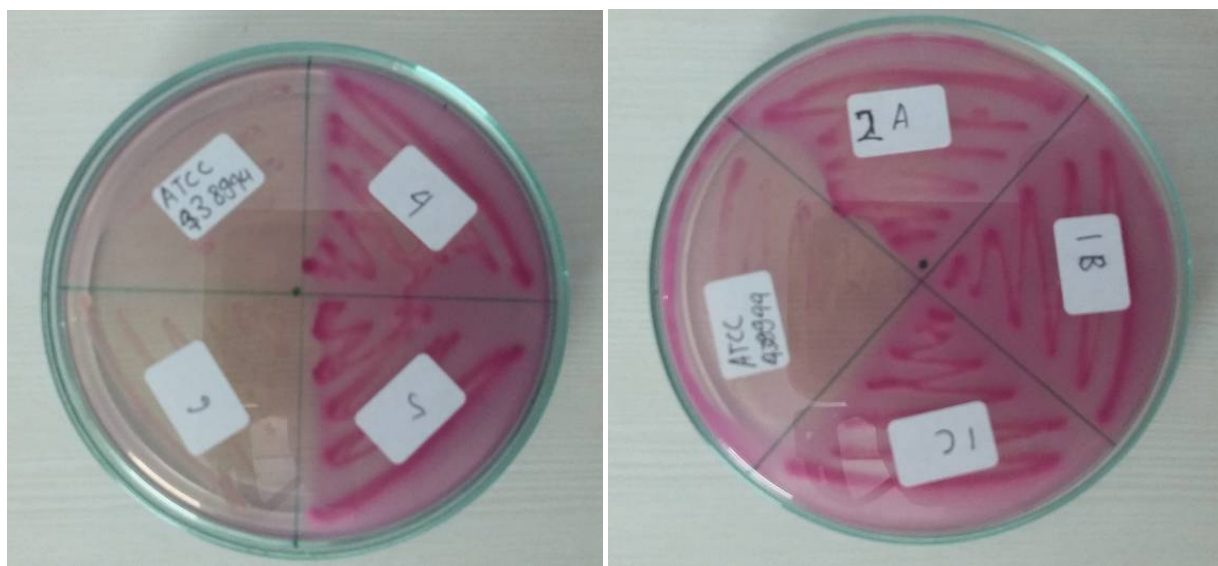

Gambar 2. Koloni E. coli $\mathrm{O} 157$ pada media sorbitol MacConkey Agar (SMAC) menujukkan bahwa sampel Nomor 2 yang berwarna bening diduga positif $E$. coli $\mathrm{O} 157: \mathrm{H} 7$. Nomor 1 sebagai kontrol E. coli O157:H7 ATCC4389

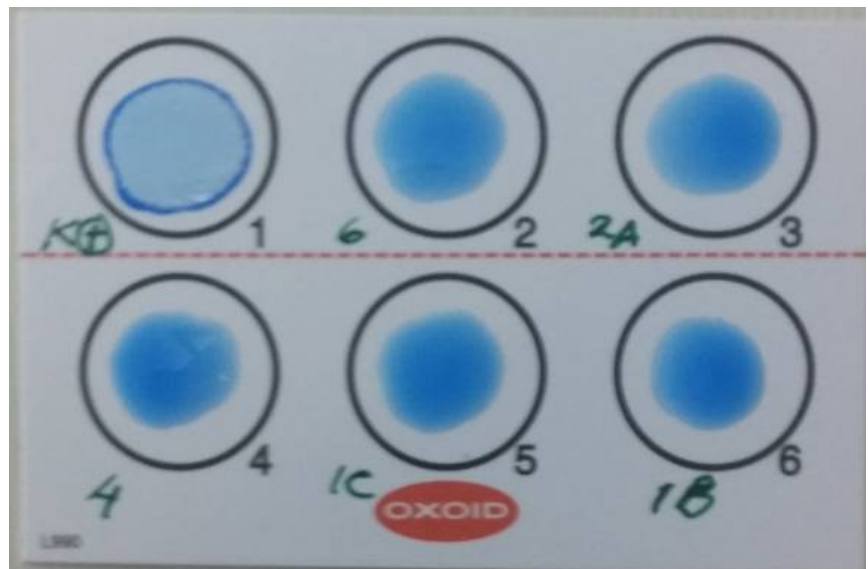

Gambar 3. Hasil uji Eschericia coli O157:H7 dengan latek agglutinin test menunjukkan negatif Eschericia coli O157: H7.

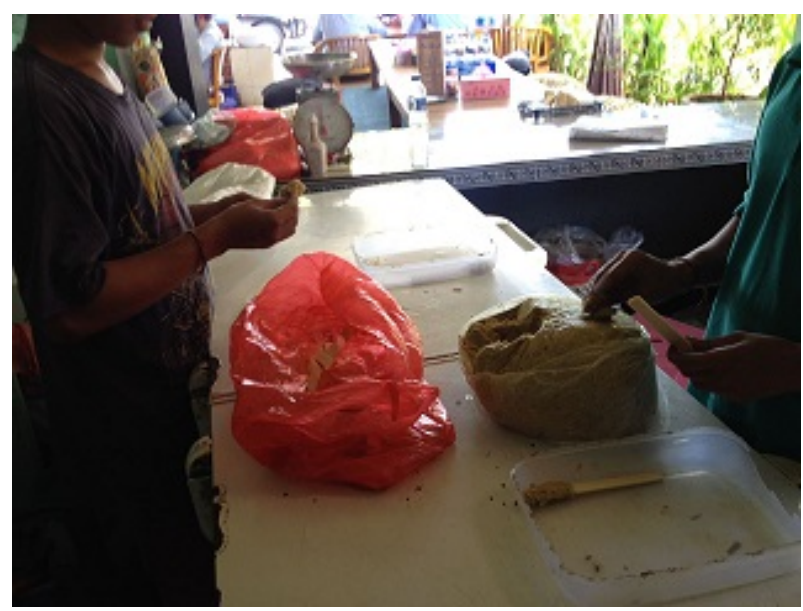

Gambar 4. Penggunaan tangan jika tidak dibersihkan dengan baik rentan mengkontaminasi, 
alat luluh yang jarang dibersihkan juga rentan mengkontaminasi.

\section{Persepsi tentang hygiene}

Beberapa pedagang mengakui tidak menggunakan alat seperti celemek, cuci tangan sebelum mengambil makanan. Mereka merasa lebih ribet untuk menyiapkan alat pelindung. Padahal ini penting untuk menghindari resiko terjadinya kontaminasi pada makanan.

"Saya malas memakai alat kayak celemek agak ribet seperti itu lagian kan tidak harus pakai begituan" (PD2)

".....he...he.. (ketawa) gak ah pakai slop tangan segala, saya gak mau agak repot jadinya. Cuci tangan saya cuci tapi kan tidak harus selalu, masak tiap ngambil makanan cuci tangan (PD5).

"......kalau habis nyusuk uang saya juga tidak cuci tangan langsung saja menyiapkan hidangan....tenaga juga kurang masak harus cuci segala. (PD3).

\section{Tempat penyimpanan daging}

Daging yang sisa disimpan dalam wadah pendingin atau freezer. Pedagang menyimpan dagingnya dalam wadah pendingin jadi mereka akan keluarkan jika ada yang membeli. masingmasing pedagang memiliki freezer untuk menyimpan bahan sate serta ikannya.

"daging saya ambil dari freezer kalau mau buat sate atau bakso kita keluarkan, ikan juga saya simpan biar awet" (PD4)

"...saya simpan di freezer di kulkas kalau masih ada sisa. Bumbunya sudah dipisahkan (PD3)

\section{Persepsi tentang kebersihan alat luluh}

Penyedia jasa yang membuat luluh atau daging cincang. Alat yang digunakan ada yang dibersihkan secara rutin ada yang hanya membersihkan setelah selesai pemakaian. Mereka juga mempertimbangkan kebersihan alat juga akan menarik pelanggan untuk datang membeli jasa mereka. Tempat yang bersih dan sehat akan membuat pelanggan mereka senang. Beberapa pemilik alat hanya mencuci alat sekedarnya tanpa disinfektan atau sabun.

"Alat saya gunakan dulu nanti kalau sudah selesai pakai baru dicuci" (PD1)

"Untuk kebersihan alat saya perhatikan itu karena terkait dengan kesenangan pelanggan juga, biasanya sehabis ada yang bawa daging kesini untuk di jadikan luluh saya langsung bersihkan. Ini kan biar pelanggan juga senang, biar bersih, sehat juga. Kalau kotor banyak lalat kan mereka juga tidak senang" (PD2)

Sebagian besar pedagang tidak memiliki alat luluh jadi biasanya mereka membawa daging untuk dicincang menjadi luluh ke tempat pengolahan daging terdekat.

"Kalau saya karena gak punya alat yah membawa ke tempat luluh itu disana....saya sudah langganan (PD4).

"Saya sudah lama langganan disana saya biasanya gak ada masalah....baik orangnya sama saya masih saudara juga" (PD6)

"Saya pertimbangkan juga sih kebersihan alatnya yah, jadi kalau bersih itu kan bagus berarti" (PD7).

"Saya sudah punya alat sendiri jadi saya sudah bersihkan itu alatnya secara rutin ini kan penting yah, apalagi mau dijual ke orang jadi ini nama baik kita" (PD3)

Hasil studi ini menunjukkan bahwa kualitas mikrobiologis Sate Languan di Pantai Lebih, Gianyar kurang baik hal ini terkait juga dengan higiene dan sanitasi pedagangnya. Sebagai salah satu objek wisata banyak wisatawan domestik dan internasional menikmati kuliner tersebut. Upaya untuk memperbaiki kualitas mikrobiologinya sangat diperlukan agar mampu menjadi kawasan wisata kuliner yang layak bagi wisatawan mancanegara.

Hasil penelitian lainnya tentang kontaminasi mikrobiologi makanan khas Bali lawar di Wilayah Kuta juga menemukan $46,55 \%$ yang positif $E$. Coli. $^{2}$ Penelitian di Pontianak juga menemukan bahwa adanya kontaminasi pada makanan laut di pasar tradisionalnnya. ${ }^{5}$ Adanya temuan E. coli pada makanan dapat menyebabkan terjadinya kasus keracunan makanan. ${ }^{6}$

Penelitian di beberapa negara juga menemukan hal yang sama bahwa penjamah makanan dapat saja memiliki pengetahuan dan sikap yang baik namun perilaku mereka masih tetap buruk. ${ }^{7,18,19,20}$ Ada banyak kasus keracunan makanan di sebabkan karena rendahnya hygiene dari penjamah makanan. Penelitian lainnya juga menunjukkan penjamah makanan yang hygiene personalnya buruk dapat menularkan infeksi saluran pencernaan. ${ }^{8}$

Penelitian ini juga menunjukkan penggunaan hygiene penjamah makanan dari pedagang seperti menggunakan masker, celemek, alat pengambil makanan masih rendah. Bahkan kecenderungan untuk mencuci tangan dengan sabun setiap mengambil barang yang terkontaminasi juga rendah. Perilaku ini justru menyebabkan terjadinya kontaminasi dari tangan ke makanan, dari alat yang digunakan jika tidak rajin di bersihkan juga menjadi sumber penularan.

Kebersihan tangan sangat penting bagi setiap orang terutama bagi penjamah makanan. Kebiasaan mencuci tangan sangat membantu dalam mencegah penularan bakteri dari tangan kepada makanan. Hal 
ini sejalan dengan penelitian yang menunjukkan bahwa ada hubungan yang sangat signifikan antara variabel kategori perilaku dengan angka kuman. ${ }^{9}$ Hasil pemeriksaan E. coli yang tidak memenuhi syarat terbanyak pada perilaku dengan kategori rendah $(66,7 \%)$, dan yang memenuhi syarat terbanyak pada responden dengan kategori sedang $(88,5 \%)$. Hasil uji statistik menunjukkan bahwa ada hubungan yang signifikan antara variabel perilaku dengan $E$. coli.Terdapat proporsi praktikhigiene penjamah makanan kurang baik lebih banyak dibandingkan dengan praktikhigiene penjamah makanan yang baik.

Hasil pengamatan di dalam penelitian ini menemukan seluruh pedagang tidak memiliki tempat sampah dengan penutup karena mereka menggunakan tempat sampah yang terbuka atau hanya menggunakan plastik, begitu pula dengan hasil observasi dari penelitian di Depok yang menunjukkan bahwa beberapa pedagang tidak menyediakan bak sampah lengkap dengan penutupnya. ${ }^{10}$ Persyaratan Hygiene Sanitasi Jasa boga menyebutkan bahwa tempat-tempat sampah seperti kantong plastik atau kertas, bak sampah tertutup harus tersedia dalam jumlah yang cukup dan diletakkan sedekat mungkin dengan sumber produksi sampah, namun dapat menghindari kemungkinan tercemarnya makanan oleh sampah. ${ }^{15,16}$ Penanggung jawab jasa boga harus memelihara semua bangunan dan fasilitas atau alatalat dengan baik untuk menghindari kemungkinan terjadinya pencemaran terhadap makanan, akumulasi debu atau jasad renik, meningkatnya suhu, akumulasi sampah, berbiaknya serangga, tikus dan genangangenangan air.

Berdasarkan hasil observasi dalam penelitian ini diketahui bahwa sebagian besar penjamah makanan tidak menggunakan celemek, sesuai dengan hasil penelitian di Palembang yang memaparkan hasil bahwa tidak ditemukan seorang pun pedagang makanan jajanan yang memakai celemek selama menjamah makanan di lokasi berdagang di lingkungan sekolah dasar. ${ }^{11}$ Pengamatan juga dilakukan terhadap penggunaan penutup kepala pada penjamah makanan. Dari 23 responden ditemukan hanya $60,9 \%$ responden yang menggunakan penutup kepala, bahkan sebagian besar $(86,9 \%)$ responden tidak mencuci tangan saat hendak menjamah makanan. Semua penjual mempunyai tempat sampah, tetapi masih ada beberapa yang tidak ada penutupnya. Praktek higiene pedagang mempengaruhi kualitas makanan yang ditangani, praktek higiene yang buruk dapat menyebabkan kontaminasi mikrobiologis pada makanan karena penjamah makanan merupakan sumber utama dan potensial dalam kontaminasi makanan dan perpindahan mikroorganisme. ${ }^{12}$

Penelitian di Depok juga menemukan bahwa keberadaan E.coli pada makanan ketoprak dan gadogado disebabkan oleh adanya kontaminasi dari penjamah itu sendiri. ${ }^{10}$ Disimpulkan bahwa ada hubungan yang bermakna antara kuku tangan penjamah makanan dengan kontaminasi makanan. Di samping itu kebiasaan tidak mencuci tangan sebelum melayani pembeli dan setelah pergi ke toilet, merupakan sumber kontaminan yang cukup berpengaruh terhadap kebersihan bahan makanan. Kebiasaan merokok yang sering terlihat pada saat mereka menunggu pembeli adalah faktor kontaminan lainnya. Kurangnya kebersihan penjamah makanan dan kontaminasi tinja juga mempengaruhi. ${ }^{21}$

Ini sesuai juga dengan penelitian di Semarang Dari 13 sampel rujak, sebanyak 9 sampel (69,2\%) mengandung $E$. coli dan sebanyak sampel (30,8\%) tidak mengandung E. coli. ${ }^{12}$ Keberadaan E. coli pada makanan tersebut diakibatkan oleh faktor pengetahuan tentang praktek higiene perorangan yang kurang. Kemungkinan, sebagian besar pedagang tidak mendapatkan penyuluhan tentang penerapan praktek higiene dalam menangani makanan. Meningkatkan pengetahuan penjamah makanan melalui pemberian pelatihan dan kursus dapat menurunkan angka kesakitan dan kematian karena makanan. ${ }^{13,17}$ Untuk mencegah terjadinya penularan penyakit yang disebabkan oleh penjamah makanan dan minuman, maka perlu adanya pengawasan dan pembinaan yang baik. Penjamah makanan berkewajiban menerapkan 6 prinsip sanitasi pangan, yaitu; pemilihan bahan, penyimpanan bahan, pengolahan, penyimpanan makanan matang, pengangkutan, dan penyajian. Meskipun sudah menjadi keharusan bagi setiap penjamah untuk menjaga kesehatan dan kebersihan, tetap harus ada pengawasan untuk memastikan seorang penjamah makanan dalam keadaan sehat ketika sedang bekerja. ${ }^{14}$

Pada penelitian ini terbukti ada kontaminasi $E$. Coli pada Sate Languan namun tidak ditemukan bakteri berjenis E. Coli O157:H7. Penelitian di India juga menunjukkan dari 106 sampel makanan ada 62\% yang positif $E$. Coli namun tidak ditemukan berjenis E. Coli O157:H7. ${ }^{22}$ Penelitian di Nigeria menemukan E. Coli O157 pada makanan olahan dari susu yang kemungkinan terkontaminasi dari peternak. ${ }^{23}$ Kontaminasi E. Coli O157:H7 sangat berbahaya karena seringkali menyebabkan kejadian luar biasa. ${ }^{24}$

\section{SIMPULAN}

Ada hubungan higiene penjamah makanan, ketersediaan sarana fasilitas sanitasi dan kepemilikan alat luluh dengan dengan kontaminasi E. coli. Terdapat cemaran E. coli pada

makanan Sate Languan namun tidak terbukti jenis $E$. coli $\mathrm{O} 157: \mathrm{H} 7$.

\section{DAFTAR PUSTAKA}

1. Trisdayanti NPE, Sawitri AAS, Sujaya. In Hygiene sanitasi dan potensi keberadaan gen virulensi E. Coli pada lawar di Kuta: Tantangan pariwisata dan kesehatan pangan di Bali. Public health and preventive medicine archive. 2015;3 (2):124-132.

2. Suter IK, Kencana Putra IN, Semadi Antara N, dan Sudana W. Studi tentang Pengolahan dan 
Keamanan Lawar (Makanan Tradisional Bali). Program Studi Teknologi Pertanian Unud. Denpasar. 1997.

3. Purnama SG, Purnama H, Subrata IM. Kualitas Mikrobiologis dan Higiene Pedagang Lawar di Kawasan Pariwisata Kabupaten Gianyar, Jurnal Kesehatan Lingkungan Indonesia. 2017. 16 (2): 56-62.

4. Suardana IW, Artama WT, Asmara W, Daryono BS. Adherence Pheno-genotypic of Escherichia coli O157:H7 Isolated from Beef, Feces of Cattle, Chicken and Human. Indonesian. Journal of Biotechnology. 2011. 16 (1): 46-52.

5. Ateba $\mathrm{CN}$, Mbewe M. Detection of Escherichia coli O157:H7 virulence genes in isolates from beef, pork, water, human and animal species in the northwest province, south Africa: public health implications. Res Microbiol. 2011. 162 (3): $240-8$.

6. Suardana IW, Utama IH, dan Wibowo MH. Identifikasi Escherichia coli O157:H7 Dari Feses Ayam Dan Uji Profil Hemolisisnya Pada Media Agar Darah. Jurnal Kedokteran Hewan. 2014. 8 (1): 1-5.

7. Lee HK, Halim HA, Thong KL, and Chail LC. Assessment of Food Safety Knowledge, Attitude, Self-Reported Practices, and Microbiological Hand Hygiene of Food Handlers. Int J Environ Res Public Health. 2017. 14(1): 55 .

8. Michaels B, Keller C, Belvins M, Paoli G, Ruthman T, Todd E, Griffith CJ. Prevention of food worker transmission of foodborne pathogens: Risk assessment and evaluation of effective hygiene intervention strategies. Food Serv. Technol. 2004. 4:31-49.

9. Cahyaningsih CT, Kushadiwijaya H, Tholib A. Hubungan Higiene Sanitasi Dan Perilaku Penjamah Makanan Dengan Kualitas Bakteriologis Peralatan Makan Di Warung Makan. Berita Kedokteran Masyarakat, 2009. 25 (4): 180-188

10. Susanna D, Hartono B. Pemantauan Kualitas Makanan Ketoprak Dan Gado-Gado Di Lingkungan Kampus UI Depok, Melalui Pemeriksaan Bakteriologis. Makara, Seri Kesehatan, 2003. 7 (1): 21-29

11. Agustina F, Pambayun R, Febry F. Higiene Dan Sanitasi Pada Pedagang Makanan Jajanan Tradisional Di Lingkungan Sekolah Dasar Di Kelurahan Demang Lebar Daun Palembang. Jurnal Ilmu Kesehatan Masyarakat, 2010. 1 (1): 53-63

12. Setyorini E. Hubungan Praktek Higiene Pedagang Dengan Keberadaan Eschericia Coli Pada Rujak Yang Di Jual Di Sekitar Kampus Universitas Negeri Semarang. Unnes Journal Of Public Health, 2013. 2 (3): 1-8

13. Naing NN, Zain MM, Abdullah N. A Study on Reliability of Questionnaire on Knowledge,
Attitude and Practice (KAP) of Food Handlers Towards Food Borne Diseases and Food Safety. International Medical Journal, 2007. 14( 4):2815.

14. Djarismawati, Sukana B, Sugiharti S. Pengetahuan dan Perilaku Penjamah tentang Sanitasi Pengolahan Makanan pada Instalasi Gizi Rumah Sakit di Jakarta. Media Litbang Kesehatan, 2004. 14 (3): 31-37

15. Kementerian Kesehatan RI. Keputusan Menteri Kesehatan Republik Indonesia Nomor 715/Menkes/SK/V/2003 Tentang Persyaratan Hygiene Sanitasi Jasaboga Menteri Kesehatan Republik Indonesia. 2003. Jakarta

16. Kementerian Kesehatan RI. Keputusan Menteri Kesehatan Republik Indonesia Nomor 942/Menkes/SK/VII/2003 tentang Pedoman Persyaratan Hygiene Sanitasi Makanan Jajanan, Depkes RI. 2003. Jakarta.

17. Zain MM, Naing NN. Sociodemographic Characteristics of Food Handlers and Knowledge, Attitude and Practice Towards Food Sanitation: A Preliminary Report. International Medical Journal. 2002.33 (2): 1-8

18. Ackerley L. Consumer awareness of food hygiene and food poisoning. Environ. Health. 1994.102:69-74.

19. Curtis V, Cousens S, Mentens T, Kenki B, Diallo I. Structured observations of hygiene behaviours in Burkira Faso: Validity, variability and utility. Bull. World Health Organ. 1993; 71:23-32.

20 Pinfold JV. Analysis of different communication channels for promoting hygiene behavior. Health Educ. Res. $1999 ; 14: 629-639$.

21 Lawan M, Mohammed B, Junaid K, Laura G, Stefano M. Detection of Pathogenic Escherichia coli in Samples Collected at an Abattoir in Zaria, Nigeria and at Different Points in the Surrounding Environment. Int. J. Environ. Res. Public Health 2015. 12: 679-691.

22 Godambe LP, Bandekar J, Shashidhar R. Species specific PCR based detection of Escherichia coli from Indian foods. Biotech, 2017. 7 (130): 1-5.

23 Yakubu Y. Shuaibu AB, Ibrahim AM, Hassan UL, Nwachukwu RJ. Risk of Shiga Toxigenic Escherichia coli O157:H7 Infection from Raw and Fermented Milk in Sokoto Metropolis, Nigeria. Journal of Pathogens. 2018: 1-6

24 Crump JA, Sulka AC, Langer AJ, Schaben C, Crielly AS, Gage R, et.al. An outbreak of Escherichia coli O157:H7 infections among visitors to a dairy farm. N Engl J Med. 2002. 347 (8). 555-560. 